\title{
7 \\ American young women at war
}

\section{Introduction: American women at war}

American women participated in the First World War long before their nation entered the conflict. Wealthy and independent women who could afford to travel joined volunteer units or offered their services independently to the Committees of the French and Belgian Red Cross. ${ }^{1}$ Their efforts were rewarded by admission into some of the most dramatic - and horrific - scenarios of the war. Nothing could have prepared them for the seriousness of the wounds they encountered. Industrial warfare was not a new phenomenon: the Second Anglo-Boer War (1899-1902) and the Russo-Japanese War (1904-5) had featured the use of machine guns and the deployment of heavy artillery. What was new, and (for most) unexpected, was the extent of the carnage. The unsuccessful assaults that characterised the first three-and-a-half years of the First World War led to massive numbers of casualties, sometimes numbering tens of thousands in one day. Typically, the wounded would arrive at field hospitals as 'rushes' more than could be coped with by even the best-staffed hospital with the most highly trained clinical personnel. ${ }^{2}$

Many American volunteer nurses enlisted with the French Red Cross and found themselves posted to field hospitals where fully trained nurses were scarce. The development of a nursing profession in France had been slow and uneven. There were very few secular training schools, and much of the country's civilian nursing care was in the hands of religious nuns who, even though they were often 
highly competent carers, had very little technical training. ${ }^{3}$ The outset of the war also saw the recruitment of large numbers of French 'lady volunteers', motivated more by patriotism than by a desire to nurse.

\section{Disillusionment and despair: meeting the realities of war}

The opportunity to cross the Atlantic and travel to the Old World of which they had heard so much fired the imaginations of many American women. Some freely admitted to having been driven by highly romantic fantasies. Shirley Millard described how she 'wanted to save France from the marauding enemy', adding that 'banners streamed in my blood; drums beat in my brain; bugles sounded in my ears.'

Millard began her published memoir of the war with a foreword in which she described how, in the mid-1930s, she had rediscovered her diary: a 'record of the year 1918', wrapped in a small French tricolour. At this point, Europe seemed to be moving inexorably towards another war, and her fear that warfare would threaten the future of her five-year-old son prompted her to write a book, somewhat eccentrically entitled I Saw Them Die. ${ }^{5}$ True to its title, the book contains numerous references to horrifying deaths in French military hospitals. Millard writes of the power of a long-forgotten diary to evoke the sights, sounds, and smells of another time. Her foreword resonates with nostalgia as she surveys the 'small pig-skin volume with a gilt clasp. The memoir is clearly intended both to offer an eye-witness account of the horror of war - a record written with pacifist intentions - and to chronicle Millard's own development from naive adventuress to war-weary woman, made wise by her experience and unable to view with equanimity the approach of another conflict.

At the outset of war, Millard's fantasies had been driven by both the romance of nursing and a more focused romantic love for a particular object:

I visualized myself driving an ambulance along the battle lines, aiding and comforting the wounded, or kneeling beside dying men in shell-torn No Man's Land. Or better still, gliding silently among hospital cots, placing a cool hand on fevered brows, lifting bound heads to moisten pain-parched lips with water ... Perhaps Ted, whom I was then regarding with some favour, would be brought back to the hospital - wounded. Oh, very slightly 
wounded, of course. Gassed a bit perhaps. Or with a sprained ankle. He would open his eyes and find me bending over him, my white veil brushing his cheek. ${ }^{6}$

Composing her memoir almost twenty years after the events it describes, Millard is conscious of both the frustrated energy and the self-absorption of youth that drove so many women to volunteer as nurses. Upon arrival in France, Millard found herself in a temporary makeshift hospital in a chateau near Soissons. On 28 March 1918, she wrote in her diary of how different hospital work was from all that she had imagined. The hospital had 3,500 beds and the wounded seemed to pour in from a 'procession of ambulances'. Once the chateau was full, many had to sleep on stretchers outside, where 'from the black shadows under the trees came their moans, their cries and sobs. 7 Millard offers a vivid impression of herself: a volunteer who was out of her depth, nursing - with neither training nor experience seriously injured trauma casualties:

Some one thrust a huge hypodermic needle and a packet of something into my hands and told me hurriedly that every man who came in must have a shot against tetanus. The soil of the battlefields was impregnated with poisons from gas and explosives. After that I was to 'get them ready' for the operating table. 'Hurry! Fast as you can!' I looked about helplessly. How on earth did one give a hypodermic? I'd never even had one. And what did 'get them ready' mean? ${ }^{8}$

Millard describes how she learned injection technique by watching other nurses and attempting to mirror their practice, and how she received some basic tuition from a friendly orderly.

Although her nursing skills left much to be desired, Millard's writing skills cannot be doubted. While they are raw and unsophisticated, her precise and vivid descriptions of what she saw leave a deep impression on the mind of the reader:

Gashes from bayonets. Flesh torn by shrapnel. Faces half shot away. Eyes seared by gas; one here with no eyes at all. I can see down into the back of his head. Here is a boy with a grey, set face. He is hanging on ... too far gone to make a sound. His stomach is blown wide open, and only held together by a few bands of sopping gauze which I must pull away. I do so, as gently as I can. The odour is sickening; the gauze is greenish yellow. Gangrene. He was wounded days ago and has been waiting in the grounds. He will die ... 
My hands get firmer, faster. I can feel the hardness of emergency setting in. Perhaps after a while I won't mind. Here is an unconscious lad with his head completely bandaged. The gauze is stiff with blood and dirt. I cut carefully and remove it, glad he is unconscious; much easier to work when they cannot feel the pain. As the last band comes off, a sickening mass spills out of the wide gash at the side of his skull. Brains! I am stunned. I cannot think what to do. No time to ask questions. Everyone around me is occupied with similar problems. Boldly I wrap my hand in sterile gauze and thrust the slippery mass back as best I can, holding the wound closed while I awkwardly tie a clean bandage around the head. It does not occur to me until afterwards that he must have been dead. ${ }^{9}$

Millard's diary is rare because it describes the experiences of an entirely untrained and inexperienced young woman. The policy of the Army Nurse Corps was to allow only fully trained nurses to accompany official medical units to Europe. ${ }^{10}$ American volunteer units like the one Millard joined worked under the auspices of the American Red Cross. Their services were welcomed by the Belgian and French military medical services. Millard appears to have been unusual in having no nursing or first-aid training at all. ${ }^{11}$ Most volunteer nurses equipped themselves with a range of basic skills and techniques - usually taught by trained nurses hired by the Red Cross. In Britain, where a war had long been anticipated, such training sessions were organised by VADs, and the preparation of volunteer nurses had attained a degree of sophistication. In the USA there was consensus among nurse leaders that it was not advisable to encourage the organised development of 'volunteer nursing' units. In May 1918, a year after America's entry into the war, leaders of the profession met at the Convention of the National Nursing Organizations in Cleveland, Ohio, to discuss the serious shortage of military nurses on the war front. They decided that the shortfall in the numbers of trained US military nurses should be made good, not by the employment of volunteers, but by the recruitment of probationer nurses via the Army School of Nursing, which had been formed in the previous year. ${ }^{12}$

The determination of US nurse leaders not to supplement their profession's numbers with semi-trained volunteers had two consequences. It brought a greater stability to nursing services on war fronts, but it also resulted in a lower investment of the professional nursing services' time and resources into the training of volunteer 
nurses. When American volunteer units did travel to Europe they were often accompanied by women with very little training or preparation of any kind. ${ }^{13}$

\section{The mystery of War Nurse}

The theme that war can damage women as well as men is taken up by feminist writer Rebecca West in her highly sensationalised War Nurse, a work that stands outside the influence of propaganda, offering a unique and highly individual perspective. ${ }^{14}$ Like Millard's less conscious work, West's writing seems to derive from a compulsion to set out the horrific consequences of war. The anonymously published War Nurse is one of the most elusive texts of the First World War. Ghost-written by West from the diaries of an anonymous volunteer nurse, known only as 'Corinne Andrews', the text contains shocking accounts of the brutality of military surgery. ${ }^{15}$ Its main purpose, however, is to convey a sense of how women, as well as men, could be irreparably damaged by war: the focus is on the destruction of the volunteer nurse herself. The book's main character is the daughter of a wealthy American who travels to Paris to work for the American Ambulance at the outset of war. The story traces her descent from optimistic-but-naive war worker, through disillusionment and flight into romance, to physical and emotional self-destruction through overwork and a damaging relationship. The sensationalist nature of the work may have led West - who, by the time it was published in book form, was a writer of some repute - to distance herself from the project. The book's main figure - the nurse - remains anonymous, leaving the reader with a sense of the unreality of what is nevertheless a powerfully told story.

The American Ambulance at Neuilly was an American volunteer hospital, operating under the auspices of the French Red Cross. It appears to have had a reputation as a quirky institution. An anonymous article, written, apparently, by two trained US nurses and published in the American Journal of Nursing, offers a light-hearted and amusing perspective on the work of its untrained volunteers:

The majority of the volunteer workers were very splendid people, and without their good, honest, hard work the hospital could not have been run. 
Mixed with those, however, were some who took the work less seriously and, although they gave the nurses some anxious moments and little help, they did furnish us with many a good laugh ... I recall the words of the naïve young lady who, when asked how a certain patient was doing, said, 'Oh, he is getting along beautifully, his temperature goes up a little more each day!. ${ }^{16}$

The 'American Ambulance' had been established in the grand buildings of the Lycée Pasteur in Neuilly-sur-Seine, a suburb of Paris. ${ }^{17}$ Trained nurses Ellen La Motte and Agnes Warner both worked there for a short time. ${ }^{18}$ The hospital appears to have been a largely effective, but highly eccentric, institution. 'Corinne Andrews', the heroine of War Nurse, appears to have spent several months there, working as a volunteer nurse.

War Nurse must be seen as having dual authorship. The publicity material produced by the publisher, the Cosmopolitan Book Corporation of New York, states that:

'Corinne Andrews' is not the real name of the woman whose war story is told here. But the story, transcribed from her diary, is authentic. The sheltered daughter of a staid New York family became a war nurse. In a new world that seemed to be built on contrasts and paradoxes, melodrama, irony and illicit romance became the stuff of matter-of-fact daily life, and with matter-of-fact sincerity she set the poignant story down. ${ }^{19}$

The two ideas that stand out from this piece of publicity are the idea that the account is 'authentic' and the claim that it has a 'matter-offact sincerity'. But what exactly are 'authenticity' and 'matter-of-fact sincerity', particularly when they are placed alongside 'paradoxes, melodrama, irony and illicit romance'? And, if the account is really transcribed from an anonymous nurse's diary, how could authorship have been attributed to Rebecca West? And can one know that the events related in the diary actually took place? The veracity of West's account is called into question not only because there is no way of knowing who 'Corinne Andrews' was, but also because the ghost-writer - West - is something of a ghost herself. Born Cicely Fairfield, West took her pen name from a character in Ibsen's play Rosmersholm. Not even Rebecca West was exactly who she claimed to be. ${ }^{20}$ And the mystery of the book's authorship goes even further than this. Rebecca West's name was removed from the book when it was published in 1930. Biographer Victoria Glendinning has 
suggested that West's original work on the serialisation of the diary in 1926 was primarily motivated by financial need: West was a single mother. ${ }^{21}$ It may be that, having achieved success and acclaim as an author by 1930, she no longer wanted to be associated with this unusual and avant-garde production of her earlier years. It may also be that she saw War Nurse as a less polished, less sophisticated piece of writing than her other works. The book's staccato passages and, at times, overwrought impressions contrast markedly with the beautiful and polished prose of her most famous early work, The Return of the Soldier, ${ }^{22}$ and it never achieved the critical acclaim of later novels such as The Fountain Overflows and The Birds Fall Down. ${ }^{23}$

To understand War Nurse it is necessary to appreciate West's insistent feminism. A campaigner for women's rights in the popular press of her time, she allowed a sense of the injustices suffered by the women of the early twentieth century resonate through her writings, along with her belief that their contributions and sacrifices were not recognised. ${ }^{24}$ This may be what drew her to the story of 'Corinne Andrews', whose health is said to have been irreparably damaged by the heavy lifting of patients to the extent that the war has left her disabled: physically and emotionally damaged and, significantly, unable to have children and fulfil her accepted role as a woman in 1920s society. 'Corinne Andrews' has been just as badly damaged as any soldier wounded by the war - just as disabled by her experience. Perhaps, then, the central message of War Nurse is that men do not have the right to claim a monopoly of suffering and sacrifice in time of war, just as they do not have the monopolistic right to claim the power to determine war's execution. ${ }^{25}$

There is no way of knowing whether the compelling style of War Nurse derives mainly from the intensity of 'Corinne Andrews"s original setting-down of her experiences in her diary or of 'Rebecca West"s skill with a pen in redrafting and developing those original experiences and ideas. The book has a remarkable intensity and verve. We learn of how 'Andrews' chose to travel to France rather than accept the stultifying life of a rich American wife; of her first encounters with the brutality at the heart of military surgery when an eye specialist hands her a shrapnel-filled eye he has just removed from a conscious patient, ordering her to 'find the piece of steel'; ${ }^{26}$ of the strange sense of 'exaltation and happiness' her work gave her; ${ }^{27}$ of the 
disillusionment that sets in, not only for her, but for her fellow workers, as the war drags on into its third year, when not even the triumph of America's entry into the conflict can settle the nagging feeling that life is meaningless. We learn of her flight (and that of many of her fellow hospital workers) into romance, as she begins an affair with an ambulance-driver-turned-air-force-pilot; of her wounding, her dramatic near-fatal collapse, and finally, the greatest disillusionment of all: the return home to an empty world, which leaves only an impotent desire to go back again to a wartime existence that can never be recaptured.

The nurse writes of her early realisation that the world is not the safe place she had assumed it to be:

It was a hard knock realizing that we fool ourselves all the time about the mastery we have over nature; that there are thousands of ways pain and suffering can hit the body which medical science can barely alleviate, which simply have to be met with courage. The only consolation was that at the same time you found how much pain and suffering there is in the world, you found something else, too. It's the fashion to talk now as if the war was utterly squalid, as if everybody went to pieces under it, and there was nothing glorious there at all. That isn't how I found it. It was the most amazing thing I've ever known, how brave these soldiers were. They came up to the operating table without flinching. They made jokes about it, called it the billiard table. ${ }^{28}$

West's writing in the earlier part of the book mirrors that of more traditionalist writers. The heroic motif is prominent. But later, when 'Andrews' has lost her own health and strength, we learn that even the courage of her fellow sufferers cannot give her hope. On her return to New York, she works as a hospital nurse for three months, yet she realises that 'the procession of pallid, stunted human misfits which passed through those wards would go on forever and ever. It just seemed hopeless to me. So I weakened and quit. There are a lot of things about which it can be said, "It was all right in the war, but it's no use in peace." ${ }_{29}$

Rebecca West's War Nurse was a hard-hitting exposé of the destructiveness of war, and of the naivety that had compelled young women as well as men - to expose themselves to its force. For Corinne Andrews, as for many other nurses, the war was somehow a 'force of nature', something that human beings were drawn into rather than 
creating for themselves. West records an incident in which Andrews encounters a young patient who is about to undergo the torture of a sixth operation on an amputation stump:

I said, 'Thank God, that kid will be going home soon.'

The doctor said, 'But he won't. Dr Laroche intends to operate again on Thursday.'

I was so mad I stopped the dressing-cart. 'But why?' I exclaimed. 'Why?

I thought he was doing so beautifully. What do we want to operate for?'

He shrugged his shoulders.

'C'est comme la guerre. Il ne faut pas chercher à comprendre.'

'It's like the war. You needn't try to understand it.'

They used to say it about everything; I tell you, they all felt as I did. As if the war was a masterless thing like the tides, and it was coming right for you. ${ }^{30}$

\section{Conclusion: the truth about the war}

Rebecca West was not the only author who chose to describe the war as if it were a 'masterless thing like the tides'. The metaphor of the war as a vast ocean that drew men into its destructive core, and then cast up their damaged bodies onto the metaphorical beach that was the 'zone of the armies' finds echoes in the writings of Maud Mortimer, Mary Borden, and Ellen La Motte. ${ }^{31}$ Describing the realities of war particularly from the perspective of someone who was nursing its wounded - was a complex endeavour. The truth about the war was not a simple matter. And exposing the inadequacies of volunteer nursing services sometimes meant exposing one's own inadequacies as Shirley Millard discovered. A writer such as Rebecca West could present the diaries of a volunteer nurse such as 'Corinne Andrews' as a succession of morality tales of war's corrosiveness; yet those diaries remain shrouded in mystery - weakening their power, and leaving the reader with a sense of not knowing whose voice is being heard.

British volunteer nurses - particularly those wealthy women who established their own volunteer hospitals - received significant positive publicity from the British national press. American volunteers were less celebrated in their own country, where, until 1917, there was ambivalence about whether Americans should be engaging in the war at all. ${ }^{32}$ Personal feelings of support for the allies - particularly for 
the French - meant that numerous women did experience a powerful compulsion to offer their services to the wounded, through volunteer units acting under the auspices of the French and Belgian Societies of the Red Cross. Many were totally unprepared for nursing work. The memoir of an inexperienced and untrained volunteer such as Shirley Millard offers an oblique perspective on the intricacies and challenges of nursing, and illustrates, more vividly than any professional nursing treatise, the importance of formal training. Rebecca West's rendition of the diary of 'Corinne Andrews' is more complex. It has some of the qualities of feminist writings such as Mabel St Clair Stobart's The Flaming Sword in Serbia and Elsewhere and ironic, pacifist treatises such as Ellen La Motte's The Backwash of War. Yet its sensationalist style implies that one of its author's main purposes was simply to attract a wide readership and sell copy.

The women who wrote about volunteer war nursing during the First World War undoubtedly had multiple motives for doing so. A desire to promote the feminist project of demonstrating that women, as well as men, could play significant roles in the war effort was sometimes accompanied by a pacifist wish simply to expose the horror of war from the perspective of one who had witnessed its direst consequences. Most nurse writers seem also to have felt that their war nursing work was the most powerful experience of their lives and one that must be shared.

\section{Notes}

1 On the involvement of American volunteers in the nursing services of the First World War, see: Christine E. Hallett, Veiled Warriors: Allied Nurses of the First World War (Oxford: Oxford University Press, 2014): 190; Jane Potter, " "I begin to feel as a normal being should, in spite of the blood and anguish in which I move”: American Women's First World War Nursing Memoirs', in Alison S. Fell and Christine E. Hallett (eds), First World War Nursing: New Perspectives (New York: Routledge, 2013): 51-68.

2 Christine Hallett, Containing Trauma: Nursing Work in the First World War (Manchester: Manchester University Press, 2009): 194-8; Hallett, Veiled Warriors: 47-54.

3 Katrin Schultheiss, Bodies and Souls: Politics and the Professionalization of Nursing in France, 1880-1922 (Cambridge, MA: Harvard University Press, 2001); Hallett, Veiled Warriors: 24-5. 
4 Shirley Millard, I Saw Them Die: Diary and Recollections of Shirley Millard, ed. Adele Comandini (London: George G. Harrap, 1936): 12.

5 Millard, I Saw Them Die: 10.

6 Millard, I Saw Them Die: 12-13.

7 Millard, I Saw Them Die: 20-1.

8 Millard, I Saw Them Die: 23-4.

9 Millard, I Saw Them Die: 26-7.

10 Mary T. Sarnecky, A History of the US Army Nurse Corps (Philadelphia: University of Pennsylvania Press, 1999): 85.

11 Millard, I Saw Them Die: 15.

12 Sarnecky, A History of the US Army Nurse Corps: 85.

13 On the Army School of Nursing, and the decision of American nurse leaders not to introduce volunteer nurses into American military hospitals, see: Hallett, Veiled Warriors: 216-17.

14 Rebecca West, War Nurse: The True Story of a Woman who Lived, Loved and Suffered on the Western Front (New York: Cosmopolitan Book Corporation, 1930): passim.

15 West, War Nurse; most examples of surgical work are between 48 and 73.

16 Anon. [K. K. and M. E. H.], 'Experiences in the American Ambulance Hospital, Neuilly, France', American Journal of Nursing, 15.7 (April 1915): 549-54 (550).

17 Anon., 'The American Ambulance in Paris', BJN (10 October 1914): 281; Anon., 'Letters from the Front: From France', BJN (17 October 1914): 306-7; Anon., 'Book of the Week: The Diary of a French Army Chaplain', BJN (30 October 1914): 369.

18 Ellen La Motte wrote an article on her experiences at the American Ambulance: Ellen N. La Motte, 'An American Nurse in Paris', The Survey, 34 (10 July 1915): 333-6. On Ellen La Motte, see Chapter 3; on Agnes Warner, see Chapter 2.

19 West, War Nurse: dust jacket publicity material, 1st edn.

20 Victoria Glendinning, Rebecca West: A Life (London: Macmillan, 1988 [1987]): 36.

21 Glendinning, Rebecca West: 108.

22 Rebecca West, The Return of the Soldier (London: Virago, 1980 [1918]).

23 Rebecca West, The Fountain Overflows (London: Virago, 1984 [1957]); Rebecca West, The Birds Fall Down (London: Macmillan, 1966). See also West's masterpiece on Yugoslavia: Rebecca West, Black Lamb and Grey Falcon: A Journey through Yugoslavia (Edinburgh: Cannongate, 2006 [1942]).

24 Glendinning, Rebecca West: 30-2, 37-40.

25 This deliberately voiced view can also be found in the writings of early pacifist feminists. See, for example, Catherine Marshall, Militarism versus Feminism (London: Virago, 1987 [1915]); E. Sylvia Pankhurst, The Home Front (London: Hutchinson, 1987 [1932]). 


\section{Volunteer girls}

26 West, War Nurse: 47.

27 West, War Nurse: 49.

28 West, War Nurse: 52.

29 West, War Nurse: 227.

30 West, War Nurse: 71-2.

31 Maud Mortimer, A Green Tent in Flanders (New York: Doubleday, Page, 1918); Mary Borden, The Forbidden Zone (London: William Heinemann, 1929); Ellen N. La Motte, The Backwash of War: The Human Wreckage of the Battlefield as Witnessed by an American Hospital Nurse (New York: G. P. Putnam's Sons and The Knickerbocker Press, 1916). For a discussion of these writings, see Chapters 2 and 3 of this book.

32 Potter, 'I begin to feel as a normal being should': 51-68. 